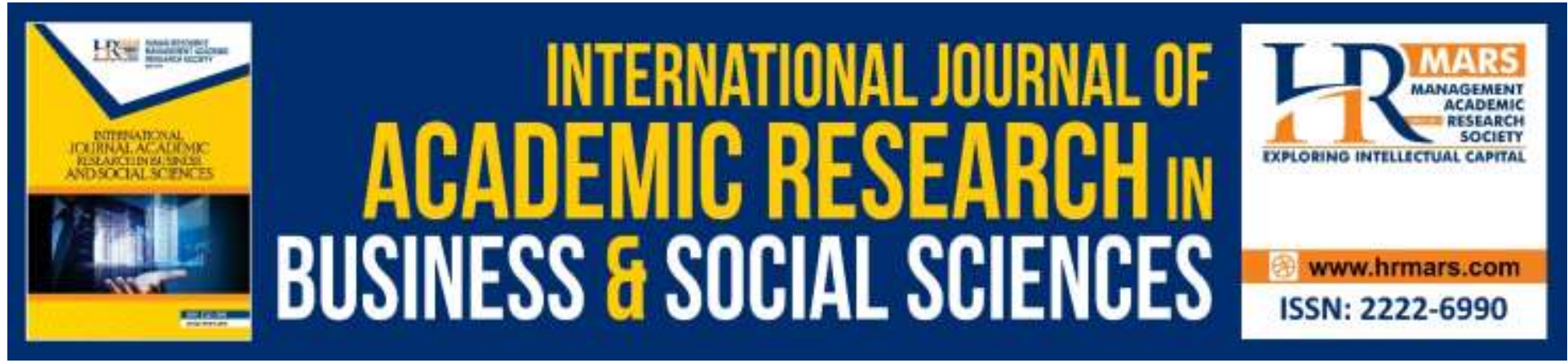

\title{
The Effect of Financial Knowledge and Financial Attitudes on Financial Behavior among University Students
}

\author{
Rusliza Yahaya, Zuraidah Zainol, Juliana Haji Osman @ Zainal Abidin, \\ Rosmini Ismail
}

To Link this Article: http://dx.doi.org/10.6007/IJARBSS/v9-i8/6205

DOI: $10.6007 /$ IJARBSS/v9-i8/6205

Received: 02 May 2019, Revised: 10 July 2019, Accepted: 30 July 2019

Published Online: 04 August 2019

In-Text Citation: (Yahaya, Zainol, Abidin, \& Ismail, 2019)

To Cite this Article: Yahaya, R., Zainol, Z., Abidin, J. H. O. @ Z., \& Ismail, R. (2019). The Effect of Financial Knowledge and Financial Attitudes on Financial Behavior among University Students. International Journal of Academic Research in Business and Social Sciences, 9(8), 22-32.

Copyright: (C) 2019 The Author(s)

Published by Human Resource Management Academic Research Society (www.hrmars.com)

This article is published under the Creative Commons Attribution (CC BY 4.0) license. Anyone may reproduce, distribute, translate and create derivative works of this article (for both commercial and non-commercial purposes), subject to full attribution to the original publication and authors. The full terms of this license may be seen at: http://creativecommons.org/licences/by/4.0/legalcode

Vol. 9, No. 8, 2019, Pg. 22 - 32

http://hrmars.com/index.php/pages/detail/IJARBSS

JOURNAL HOMEPAGE

Full Terms \& Conditions of access and use can be found at http://hrmars.com/index.php/pages/detail/publication-ethics 


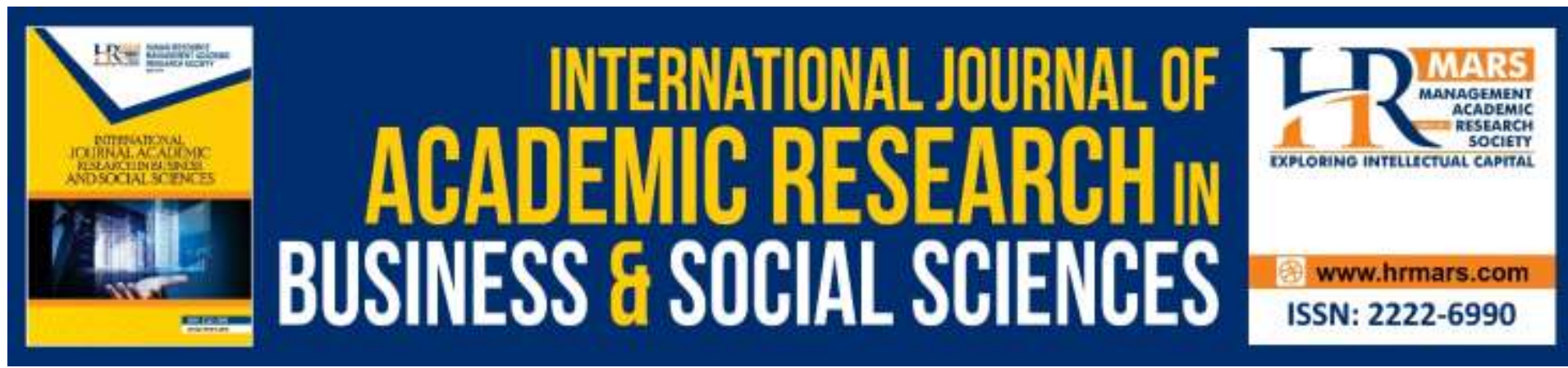

\title{
The Effect of Financial Knowledge and Financial Attitudes on Financial Behavior among University Students
}

\author{
Rusliza Yahaya, Zuraidah Zainol, Juliana Haji Osman @ Zainal \\ Abidin, Rosmini Ismail \\ Universiti Pendidikan Sultan Idris, Malaysia
}

\begin{abstract}
This study aims to examine financial literacy among university students in Malaysia. Specifically, this study attempts to examine the relationship between financial knowledge and financial attitudes, and also the effects of these variables on financial behavior among university students. Data was gathered from a sample of 370 university students through the survey method. The data was analysed using simple linear regression and multiple regression analysis. The findings reveal that the respondents have moderate level of financial knowledge. Respondents who took Financial Management course have higher level of financial knowledge compared to those who did not take any Financial Management course. Financial knowledge significantly influenced financial attitudes, and financial attitudes significantly influenced financial behavior. On the other hand, financial knowledge does not have any significant influence on financial behavior. This study enriched the literature by identifying factors that influenced financial behavior and provided suggestions to be practiced by universities in developing good financial attitude and financial behavior of students.

Keywords: Financial Literacy, Financial Knowledge, Financial Attitude, Financial Behavior, Financial Well-being
\end{abstract}

\section{Introduction}

Financial literacy is crucial nowadays due to growth in financial market. Thus, in order to make a sound financial decision individual should be equipped with good financial knowledge and attitudes. Unfortunately, today's young adult especially university students were less capable in handling their own personal finances (Chinen \& Endo, 2012). Some of them may find that they are in the trouble of making ends meet and sometimes or often are short of money (Schors, 2016). Due to this, people will look for external financial resources to support their demands of resources in credit like borrowing loan or spend on credit card. Most developed and developing countries have concerns about low savings rates and high credit card debt among individual (Borodich, Deplazes, Kardash, \& Kovzik 2010). Therefore, many countries 
have emphasized the importance of financial education as most young generation are not prepared to face financial challenges in the future.

Financial problem becomes a common problem among young adults. This problem happens because they lack financial knowledge and have to make difficult financial decisions at a young age especially in the early stages of their career. This led them to make the wrong decision that ultimately had a devastating effect on their lives. Hence, policymakers need to devise effective strategies to reduce those problems as well as to help young population to gain financial knowledge (Lusardi, Mitchell, and Curto, 2010). Those financial problems also arise due to the diversity and ongoing changes in financial markets and financial services industry (Mandell \& Klein, 2009). Thus, financial literacy plays an important role for individuals in identifying and differentiating various providers, products and services in order to achieve financial well-being (Wagland \& Taylor, 2009).

Today's young people often face challenges in university life because of their limited financial management capabilities (Lusardi, et. al., 2010; Mandell \& Klein, 2009). In contrast, students who are financially literate are less likely to face financial troubles as they can manage their debt better and are more likely to make right choices about money such as saving for future. Many countries have already focused on the financial literacy among their population and are promoting financial literacy by imparting financial education (Bushan \& Medury, 2013). Moreover, developed countries have realized that, under current economic conditions, it is important to ensure that their people have higher financial ability than ever (Suchuahi, 2013). According to Borodich, et. al., (2010), young people in particular, have insufficient knowledge about financial management that lead to making bad financial decisions. This is a crucial issue as a financially illiterate society can create several problems in the economy of the country. Despite the many studies that have examine financial literacy among students (Chen \& Volpe, 1998; Sabri \& MacDonald, 2010; Cameron et al, 2013; Mohamad Shamsuri et al, 2017), there is relatively little previous research that links financial knowledge, financial attitude, and financial behavior. Thus this study will examine these constructs by using financial literacy model developed by Potrich et al (2016).

\section{Objectives}

This study seeks to examine:

1. The level of financial literacy among university students.

2. The effect of financial knowledge on financial attitudes among students.

3. The effect of financial knowledge and financial attitudes on financial behavior among students.

\section{Literature Review}

Financial literacy is the ability to make sound judgements and make effective decisions regarding the use and management of money. The actual definition of financial literacy is in fact not clear and has never been universally agreed. Financial literacy means the way individuals manage money can be seen in terms of terms of insurance, investment, savings and in terms of budget preparation (Mahdzan \& Tabiani,2013). Financial literacy focuses on three dimensions or three aspects: financial knowledge, financial attitude and financial behavior (OECD, 2012; Atkinson \& Messy, 2012). Indeed many factors actually affect the level 
of financial literacy among individuals. In today's challenging financial landscape, individual and household needs are increasing, and certainly stimulate demand for different types of financial products.

Financial literacy is a combination of knowledge, attitudes, behaviors, awareness and capabilities required to make financial decisions and for individuals achieving wealth (OECD, 2012). In the literature, the term financial literacy is frequently used to refer to financial education and financial knowledge. However, Potrich et al (2016) stressed that financial literacy is conceptually has a deeper meaning. Financial literacy has been defined as the level of financial knowledge and the capability to use the knowledge to increase financial position (Lusardi \& Mitchell, 2014; Huhman \& McQuitty, 2009). Huhmann and McQuitty (2009) have developed a conceptual model of financial literacy, which includes three components: capacity, prior knowledge, and proficiency. Based on this model, financial education contributes to financial literacy through enhancing consumers' ability to learn, obtain, and apply financial knowledge.

Some authors defined financial literacy as financial capability, which refers to the ability to use financial knowledge and perform desirable financial behaviors to achieve financial wellbeing (Xiao, Chen \& Chen, 2014). Anjali (2016) posit that financial literacy level of an individual depends on one's financial needs and behavior. Potrich et al. (2016) suggests that financial literacy is a combination of three components i.e financial knowledge, financial attitude and financial behavior. They developed three models of financial literacy and make comparisons of the models for assessing financial literacy of students in Brazil. Their best model demonstrated that financial attitude and financial knowledge influenced financial behavior of the students.

There have been many studies carried out among young people and students on financial literacy. There is considerable evidence that financial education increases financial literacy and encourages desirable financial behaviors of individuals (Lusardi \& Mitchell, 2007). Previous research also shows that higher financial literacy and good financial behaviors benefit the nation (Chen \& Volpe, 1998; Lusardi \& Mitchell, 2007). Financial education and attitudes are also important predictor of financial literacy. Sholehah et al (2017) found that family influence, financial attitude and financial knowledge have significant positive relationship towards financial literacy. Albeerdy \& Gharleghi (2015) showed that financial education, financial socialization instruments and the attitudes towards money had a direct impact on financial literacy of university students in Malaysia. They also found that financial education was the most influential factor of financial literacy. In another study, Ergun (2017) investigated the relationship between financial behavior and financial knowledge of university students across five European countries. They found that financial education improve financial literacy among students and those who took finance course from university were more knowledgeable than those who got the information about financial issues from social media.

Previous studies have shown that college students have insufficient knowledge to manage their personal finance effectively (Chen \& Volpe, 1998; Sabri \& MacDonald, 2010; Cameron et al, 2013; Mohamad Shamsuri et al, 2017). Indeed, the life and financial needs in higher 
education institutions today are very different from the past. Therefore, financial management knowledge and skills are crucial at university level (Chen \& Volpe, 1998). Nevertheless, exposure to financial management is very limited and minimal that students face problems in their university life. Therefore, it is necessary to improve the financial literacy of individuals particularly for final year students who will join workforce so that they have positive financial management attitudes.

In Malaysia, the government attempted to enhance financial literacy and capability of the nation by integrating Economic Transformation Program (ETP) into school curriculums. In addition, credit counseling and debt management agency (AKPK) are available for those who need financial advices (Bank Negara Malaysia, 2013). The intentions of the programs launched are to create financial awareness and to improve financial knowledge among Malaysians. Surprisingly, despite all the efforts, the bankruptcy rate is still alarming in Malaysia. The bankruptcy cases increased from 16,228 cases in year 2010 to 19,588 cases in year 2016(Department of Insolvency, 2016). The increasing trend of the bankruptcy cases represent that there is an unsolved problem and there is a need to improve financial skills of Malaysian. This research is important as we believe that financial knowledge is associated with financial attitude. In recent years several programs have been developed to promote and enhance financial education to Malaysian students. Unfortunately, little is still known about whether financial knowledge is actually associated with financial attitudes and financial behavior of individual. Therefore, this study is done to analyse the association between financial knowledge and financial attitude, and also the influence of financial knowledge and financial attitude on financial behavior of university students. By understanding this issue may contribute to which factors have a significant role in educating financial matter among university students. Thus, it may provide some input to guide policymakers in formulating strategy to overcome rising number of bankruptcies in Malaysia.

\section{Methodology}

A total of 370 students from selected higher education institutions were chosen as sample of this study. Data was collected using questionnaire survey. All the measurement items were adapted from the previous studies. The instrument used were the set of questionnaires composed of four parts. Part A consists of questionnaires to collect demographic information. Part B consists of twenty questions with a five-point likert scale (1=never, $5=$ =always) that will measure financial behavior. These questions will be used to analyse university student behavior regarding the use of personal credit, planned consumption, investments and savings. The higher the score, the better is financial behavior of the students. Part $\mathrm{C}$ will measure financial knowledge. This part consists of twenty items concerning personal finance that were adapted from Sabri et al (2010). Questions were related to respondents' knowledge about financial records, credits, savings, investment, time value of money, wills, insurance, retirement, and other general knowledge on personal finance. Three options of answer were given to respondents such as "true", "false", and "not sure". Each correct answer will receive a score of 1 point, whereas no point is given to the wrong and not sure answer. The higher the score, the better is the level of financial knowledge. The final part of the questionnaire, Part $D$ consists of nine questions to evaluate financial attitude. The questions utilized a fivepoint Likert scale that ranged from 1 (absolutely disagree) to 5 (absolutely agree). Higher scores indicate good financial attitude. 
Cronbach's alpha was used to assess the reliability of the scales. Before performing the reliability analysis, all negatively worded items in the scales were reversed. The Cronbach's alpha scores for financial knowledge scale (0.69), financial attitude scale (0.89) and financial behavior scale (0.84) were adequate, indicating high reliability of scales.

\section{Results}

Table 1 provides summaries of the respondents' demographic profile. Of the total number of 370 respondents, 77.3 percent were female, and 22.7 percent were male. The respondents were grouped into two categories: Faculty of business and management (46.8 percent) and other faculties (53.2 percent). The demographic information also indicates that 39.5 percent of the respondents had CGPA score above 3.50 and only 30.3 percent of the respondents have taken Financial Management Course.

Table 1. Demographic profiles of respondents

\begin{tabular}{llcc}
\hline Profiles & Description & Frequency (N) & Percentage (\%) \\
\hline Gender & Male & 84 & 22.7 \\
& Female & 286 & 77.3 \\
\hline Faculty & Business & 173 & 46.8 \\
& Other Faculties & 197 & 53.2 \\
\hline CGPA & Less than 3.0 & 104 & 28.1 \\
& $3.01-3.50$ & 120 & 32.4 \\
& $3.50-4.00$ & 146 & 39.5 \\
\hline Financial Management & Yes & 112 & 30.3 \\
Course & & & \\
& No & 258 & 69.7 \\
\hline
\end{tabular}

Table 2 shows result of financial knowledge correct responses. Financial knowledge was measured by testing for correct answers on 20 questions. Respondents were asked whether each of twenty financial knowledge items is true, false, or not sure. The result revealed that respondents have very low scores on questions regarding insurance and savings. Only six percent of the respondents answered correctly on items "buying insurance is the best form of investment". For item "savings is the remaining of the income after it has been deducted from expenses", only 12.2 percent knew the correct answer.

A descriptive analysis was calculated for the overall and for each question of the financial knowledge to examine further the financial knowledge level of the respondents. To calculate a summary indicator of student financial knowledge, scores for all items were summed. The average score is 10.32 with a standard deviation of 2.58 . The result revealed that the respondents have moderate level of financial knowledge. Three cut-off scores were used to determine the level of financial knowledge. Respondents with a score from 0-6 were considered to have a low level of financial knowledge. Respondents having a score from 7-12 were considered to have a moderate level of financial knowledge. Respondents with a score from 13 to 20 were considered to have a high level of financial knowledge. Results shown in Table 3 indicated the majority (71.6 percent) of the respondents were rated as having 
moderate level of financial knowledge while only 20.8 percent were rated as having high level of financial knowledge. The remaining 7.6 percent were rated as having low level of financial knowledge.

Table 2 Descriptive statistics of financial knowledge items

\begin{tabular}{lc}
\hline & $\begin{array}{c}\text { Correct Answer } \\
\text { (percentage) }\end{array}$ \\
\hline Buying merchandise on credits would reduce purchasing power in the & 61.0 \\
future & \\
Increasing in price would reduce purchasing power & 88.1 \\
The balance sheet reflect the financial position & 72.6 \\
Owners of credit cards can purchase without limits & 75.1 \\
We have overspend if we use our savings to buy daily needs & 79.1 \\
The savings is doubled its value after ten years & 49.2 \\
Savings is the remaining of the income after it has been deducted from & 12.2 \\
expenses & \\
The interest influences the saving value in the future to come & 83.0 \\
Income statement describes both the income and expenses at certain & 17.5 \\
date & \\
Will is not needed for family & 83.8 \\
Buying insurance is the best form of investment & 6.0 \\
Interest rate for Saving account is higher than interest rate for fixed & 30.0 \\
deposit account & \\
Life insurance protect the policy holder from financial burdens & 27.3 \\
Credit card increase the purchasing power of an individual & 25.6 \\
A person can spend 20\% above his/her net income to pay for monthly & 17.6 \\
instalment & \\
Cash withdrawal using credit card is a low cost source of finance & 46.2 \\
All types of investments always yields profit & 67.9 \\
We can take a loan for investment & 33.8 \\
Employee Provident Fund contribution is sufficient for retirement & 74.6 \\
A family should have an emergency savings of at least 3 months of the & 84.9 \\
family income & \\
\hline
\end{tabular}

Table 3 Level of financial knowledge

\begin{tabular}{lcc}
\hline Category & Frequency & Percentage \\
\hline Low & 28 & 7.6 \\
Moderate & 265 & 71.6 \\
High & 77 & 20.8 \\
\hline
\end{tabular}

An independent sample t-test was conducted to compare the financial knowledge scores for males and females. There was no significant difference in scores for males ( $M=9.90, S D=3.00)$ and females ( $M=10.25, S D=2.43) ; t(368)=-1.69, p=0.09$ (two-tailed). 
An independent sample t-test was conducted to compare the financial knowledge scores for respondents who have taken Financial Management course and those who have not. There was a significant difference in scores for respondents who have taken Financial Management course $(M=11.18, S D=2.32)$ and respondents who have not taken Financial Management course $(M=9.95, S D=2.60) ; t(368)=4.292, p=0.000$ (two-tailed).

The effect of financial knowledge on students' financial attitude was investigated using simple linear regression. Preliminary analyses were performed to ensure no violation of the assumptions of normality, linearity, multicollinearity and homoscedasticity. Results in Table 4 showed the value of $R^{2}$ was 0.036 (adjusted $R^{2}$ was 0.033 ). This means that financial knowledge explains 3.6 percent of the variance in financial attitude. The ANOVA table showed the value of $F(1,368)=13.546, p<0.000$, a value that was highly significant.

Table 4 Simple linear regression analysis

\begin{tabular}{lcccccc}
\hline Model & $\mathbf{R}$ & $\mathbf{R}^{\mathbf{2}}$ & $\begin{array}{c}\text { Adjusted } \\
\mathbf{R}^{\mathbf{2}}\end{array}$ & $\begin{array}{c}\text { Std. Error of } \\
\text { the Estimate }\end{array}$ & $\mathbf{F}$ & Sig \\
\hline Variable & 0.188 & 0.036 & 0.033 & 0.49219 & 13.546 & 0.000 \\
& $\begin{array}{c}\text { Standardized } \\
\text { Beta }\end{array}$ & & $\mathrm{T}$ & Sig \\
\hline Financial Knowledge & 0.188 & & 3.681 & 0.000 \\
\hline
\end{tabular}

Note: $* \mathrm{p}<.05, * * \mathrm{p}<.01, * * * \mathrm{p}<.001$

A multiple regression analysis was conducted to assess the simultaneous effects of financial knowledge and financial attitudes on students' financial behavior. The results in table 5 showed the value of $R^{2}$ was 0.158 , a value that was significant, $F(2,367)=34.53$, $M S_{\text {residual }}=0.188, p<0.001$. The standard error of the estimate was 0.43 . The result revealed that the model explained $15.8 \%$ of the variance in financial behavior. This reveals that there is a huge potential that other factors explain the financial behavior of the students. The beta value for variable financial attitude was the largest $(0.368)$ and was significant. This means that financial attitude made the strongest statistically significant unique contribution to explaining financial behavior. However, financial knowledge did not demonstrate any significant influence on financial behavior.

Table 5 Multiple regression analysis

\begin{tabular}{lcccccc}
\hline Model & $\mathbf{R}$ & $\mathbf{R}^{\mathbf{2}}$ & $\begin{array}{c}\text { Adjusted } \\
\mathbf{R}^{\mathbf{2}}\end{array}$ & $\begin{array}{c}\text { Std. Error of } \\
\text { the Estimate }\end{array}$ & $\mathbf{F}$ & Sig \\
& 0.398 & 0.158 & 0.154 & 0.43352 & 34.53 & 0.000 \\
\hline Variable & $\begin{array}{c}\text { Standardized } \\
\text { Beta }\end{array}$ & & $\mathrm{T}$ & & Sig \\
& 0.03 & & 0.617 & 0.538 \\
\hline Financial Knowledge & 0.391 & & 8.023 & 0.000 \\
\hline Financial Attitude & & & & & \\
\hline
\end{tabular}

Note: ${ }^{*} p<.05,{ }^{* *} p<.01,{ }^{* * *} p<.001$ 


\section{Discussion and Conclusion}

The study analyzed financial literacy among university students in Malaysia. This research also identifies the influence of financial knowledge and financial attitude on financial behavior of university students. In general, the result shows majority of respondents have moderate level of financial knowledge. Respondents have very low scores on items regarding insurance and savings. They do not understand the purpose of having insurance as majority of them thought that having insurance is a form of investment. Findings also showed respondents who have completed Financial Management course have better financial knowledge compared to those who did not take any Financial Management course. The result revealed that financial knowledge significantly influenced financial attitudes, and financial attitudes significantly influenced financial behavior. However, this study found that financial knowledge does not have any significant influence on financial behavior.

The result of this study is consistent with Ergun (2017) that attending Financial Management course did have a positive and significant impact on financial knowledge. Our findings highlight that Financial Management course must be emphasized in university as part of the curriculum. Finance course and seminar make students aware of the importance of good financial behavior (Borden et al., 2008). Consistent with Gill and Bhattacharya (2017), this research found that financial knowledge significantly influenced financial attitude. Potrich et al (2016) and Yong, Yew and Wee (2018) found that both financial knowledge and financial attitude influenced positively the financial behavior. However, consistent with Hancock et al. (2013), this study found that only financial attitude was significantly influenced financial behavior. In contrast, financial knowledge was not a significant predictor of financial behavior. Previous studies have also observed that financial knowledge does not directly associated with good financial behavior (Borden et al, 2008; Hancok et al, 2013; Henader \& Cuder, 2019; Tang \& Baker, 2016). It was found that financial knowledge is important but not sufficient to result in good behavior. Therefore, it appears that simply having good financial knowledge may not translate into consistent prudent behavior (Borden et al. 2008). It is important to take note that the model in this study only explains $15.8 \%$ of the variance in financial behavior. This result implies that there are other factors that will contribute to financial behavior. Further studies that include more variables as the potential predicting factors for financial behavior are suggested, and future research may wish to test the influence of financial knowledge on short-term and long-term financial behavior. It is important to identify financial behavior factors because it affects the financial well-being of an individual.

This study explores financial literacy based on a behavioral approach. This study provides insightful ideas for students, policy makers and educators regarding financial knowledge, financial attitudes, and financial behavior. This study contributes to existing literature on the needs to incorporate financial course in university curriculum. This study has shown that university students are lack of financial knowledge. Thus, it is importance to provide effective finance courses in order to improve financial knowledge, financial attitude, and financial behavior of university students.

\section{Acknowledgement}

This research is funded by Universiti Pendidikan Sultan Idris under Geran Penyelidikan Universiti (Research Code: 2018-0025-107-1). 


\section{Corresponding Author}

Rusliza Yahaya

Senior Lecturer

Universiti Pendidikan Sultan Idris

35900, Tanjung Malim, Perak

Malaysia

Email: rusliza@fpe.upsi.edu.my

\section{References}

Albeerdy, M. I., \& Gharleghi, B. (2015). Determinants of the financial literacy among college students in Malaysia. International Journal of Business Administration, 6(3)15-25

Anjali, D. (2016). Financial literacy among women. A sample study in the kamrup district Assam. International Journal of Economic and Business Review, 4(2), 144-147.

Bank Negara Malaysia (2013). Annual Report. Central Bank of Malaysia, Kuala Lumpur

Borden, L. M., Lee, S. A., Serido, J., \& Collins, D. (2008). Changing college students' financial knowledge, attitudes, and behavior through seminar participation. Journal of Family and Economic Issues, 29, 24-40

Borodich, S., Deplazes, S., Kardash, N., \& Kovzik, A. (2010). Comparative analysis of the level of financial literacy among students in the U.S., Belarus, and Japan. Journal of Economics and Economic Education Research, 11 (3), 71-86.

Bushan, P. \& Medury, Y. (2013). Financial literacy and its determinants. International Journal of Engineering, Business and Enterprise Applications, 13(145), 155.

Chen, H. \& Volpe, R. P. (1998). An analysis of personal financial literacy among college students. Financial Services Review, 7(2), 107-108.

Chinen, K., \& Endo, H. (2012). Effect of attitude and background on personal financial ability: a student survey in the United State. International Journal of Management, 29 (1), 33 45.

Department of Insolvency Malaysia (2016). Annual Report of BHEUU 2016

Ergun, K. (2017). Financial literacy among university students: A study in eight European countries. International Journal of Consumer Studies, 42, 2-15.

Gill, A., \& Bhattacharya, R. (2017). The interaction of financial attitudes and financial knowledge: Evidence for low-income Hispanic family. Atlantic Economic Journal, 45, 497-510

Hancok, A. M, Jorgensen, B. L., \& Swanson, M. S. (2013). College students and credit card use: The role of parents, work experience, financial knowledge, and credit card attitudes. Journal of Family and Economic Issues, 34, 369-381

Henager, R., \& Cude, B. J. (2019). Financial literacy of high school graduates: Long- and shortterm financial behavior by age group. Journal of Family and Economic Issues, 40, 564575

Huhmann, B. A., \& McQuitty, S. (2009). A model of consumer financial numeracy. International Journal of Bank Marketing, 27(4), 270-293

Lusardi, A. \& Mitchell, O. S. (2007). Financial literacy and retirement preparedness: evidence and implications for financial education. Bussiness Economics, 42(1), 35-44.

Lusardi, A., Mitchell, O. S. \& Curto, V. (2010). Financial literacy among young. The Journal of Consumer Affairs, 44(2), 358-380. 
Lusardi, A. \& Mitchell, O. S. (2014). The economic importance of financial literacy: theory and evidence, Journal of Economic Literature, 52(1), 5-44.

Mahdzan, N. S. \& Tabiani, S. (2013). The impact of financial literacy on individual saving: an exploratory study in the Malaysian context. Transformation in Business \& Economics, 12(1), 41-55.

Mandell, L. \& Klein, L. S. (2009). The impact of financial literacy education on subsequent financial behavior. Journal of Financial Counselling and Planning, 20 (1), 15-24.

Mohd. Shamsuri, G., Ilyani, A., Aishah, S. M., Afizah, N. M. A., \& Azmi, M. (2017). Personal financial literacy among high school students in Raub, Pahang, Malaysia. Journal of Engineering and Applied Sciences 12(7), 1830-1834.OECD. (2005). Recommendation on principles and good practices for financial ceducation and awareness. Retrieved from http://www.oecd.org.finance/financial-education/35108560.pdf

Potrich, A. C. G., Vieira, K. M., \& Mendes-Da-Silva, W. (2016). Development of a financial literacy model for university students. Management Research Review, 39(3), 356-376.

Sabri, M. F. \& MacDonald, M. (2010). Saving behavior and financial problem among college students: the role of financial literacy in Malaysia. Cross Cultural Communication, 6(3), 103-110.

Sucuahi, W. (2013). Determinants of Financial Literacy of Micro Entrepreneurs in Davao City. International Journal of Accounting Research, 1(1), 45.

Tang, N., \& Baker, A. (2016). Self-esteem, financial knowledge, and financial behavior. Journal of Economic Psychology, 54, 164-176

Wagland, S. P., \& Taylor, S. (2009). When it comes to financial literacy, is gender really an issue. The Australasian Accounting Business \& Finance Journal, 3(1), 13-25.

Xiao, J. J., Chen, C., \& Chen, F. (2014). Consumer financial capability and financial satisfaction. Social Indicators Research, 118(1), 415-432.

Yong, C., Yew, S., \& Wee, C. (2018). Financial knowledge, attitude and behaviour of young working adults in Malaysia. Institutions and Economies, 10(4), 21-48. 